\title{
Evaluation of viral and prokaryotic community dynamics in Alvord Desert hot springs, Oregon, USA
}

\author{
M. H. Lee ${ }^{1, *}$, J. L. Keams ${ }^{2}$, D. W. Helzer ${ }^{2}$, O. P. Leiser ${ }^{2}$, M. A. Ochoa ${ }^{2}$, S. A. Connon ${ }^{3}$, \\ T. S. Magnuson ${ }^{3}$, M. E. Watwood ${ }^{3}$ \\ ${ }^{1}$ North Wind, Inc., 1425 Higham Street, Idaho Falls, Idaho 83402, USA \\ ${ }^{2}$ Northern Arizona University, Department of Biological Sciences, PO Box 5640, Flagstaff, Arizona 86011, USA \\ ${ }^{3}$ Idaho State University, Department of Biological Sciences, 65 Memorial Drive, Pocatello, Idaho 83209, USA
}

\begin{abstract}
Recent studies have revealed that prokaryotes and viruses are abundant in extreme environments. However, almost nothing is known about viral contributions to community dynamics and ecosystem function in such environments. In the present study, sediment/mat and water samples from 2 separate thermal areas (Mickey and Borax) within the Alvord Desert Basin, Oregon, USA, were analyzed for prokaryotic and viral abundance, viral decay and production. Springs sampled at Mickey ranged in temperature from 61 to $94^{\circ} \mathrm{C}$, and those at Borax from 61 to $96^{\circ} \mathrm{C}_{;}$all springs were near-neutral in $\mathrm{pH}$. The total number of virus-like particles $\left(10^{6}\right.$ particles $\mathrm{ml}^{-1}$, Yo-Pro-1) exceeded total prokaryotic cell counts (DAPI staining, $10^{5}$ cells ml ${ }^{-1}$ ). Virus to bacterium ratios for these systems ranged from 4.81 to 18.87 . Viral production and decay rates were determined for sediment/mat samples and water from each hot spring; viral turnover rates ranged from 0.27 to $1.00 \mathrm{~h}^{-1}$. Lysis rates of approximately $9.50 \%$ of cells $\mathrm{h}^{-1}$ in Borax springs vs. $21.70 \%$ in Mickey springs were extrapolated from viral production rates. Decay rates determined from hot springs at Mickey ranged from 0.09 to $0.20 \mathrm{~h}^{-1}$, corresponding to turnover times of 5 to $11 \mathrm{~h}$, while decay rates at Borax corresponded to viral turnover times of 12 to $14 \mathrm{~h}$. Exposure of water samples to mitomycin C yielded lysogeny rates of 18 to $21 \%$ for the total prokaryotic communities in any given sample. Together, these data show that viruses exert an important influence on microbial communities and play a significant role in extreme thermal environments.
\end{abstract}

KEY WORDS: Viruses $\cdot$ Extreme ecosystems $\cdot$ Production $\cdot$ Viral decay $\cdot$ Turnover rate $\cdot$ Lysogeny Community dynamics

Resale or republication not permitted without written consent of the publisher

\section{INTRODUCTION}

Research in the last decade has consistently demonstrated that viruses have high abundances $\left(10^{6}\right.$ to $10^{10} \mathrm{ml}^{-1}$ water or $\mathrm{cm}^{-3}$ sediment), outnumber prokaryotic densities by an order of magnitude, and contribute significantly to both microbial and phytoplankton mortality (Wilhelm \& Suttle 1999, Wommack \& Colwell 2000). Consequently, viruses are now considered to be ubiquitous and integral parts of aquatic food webs (Wommack \& Colwell 2000). Viral communities have been shown to have profound effects on biogeochemical cycling, microbial loop dynamics, and potentially host diversity (Fuhr- man 1999, Weinbauer \& Rassoulzadegan 2004, Hambly \& Suttle 2005).

While viral ecology has been studied in a wide range of aquatic habitats including rivers, lakes, oceans, sea ice, and salterns, (Fuhrman \& Suttle 1993, Guixa-Boixereu et al. 1996, Wommack \& Colwell 2000), little is known about the abundance and importance of the viral ecology in extreme ecosystems, such as hot springs. The influence of viruses on microbial communities in such environments has only recently been investigated (Breitbart et al. 2004), even though research has shown that unique and complex microbial communities exist in these habitats (Rice et al. 2001, 2004, Haring et al. 2005). Further, little is known about 
the processes responsible for regulating viral densities in extreme environments.

It has been hypothesized that viruses are the sole predators of prokaryotes in hot spring environments, due to the extreme temperatures which prohibit growth of eukaryotes as well as many prokaryotes (Breitbart et al. 2004). In this context, the effect of viral communities on bacterial and archaeal population densities and function may be amplified accordingly (Breitbart et al. 2004); therefore, these environments can and should serve as models for studying community dynamics. Very little is known about viral populations in extreme environments and the potential role they play in regulating community dynamics; to date, only one other study has examined the total 'free' viral community and its effects on the indigenous microbial community (Breitbart et al. 2004).

Several different techniques and experimental approaches have been developed to assess viral production (Wilhelm et al. 2002, Hewson \& Fuhrman 2003) and decay (Heldal \& Bratbak 1991, Bratbak et al. 1992). The technique that most directly assesses viral production removes viruses from the sample and retains infected prokaryotes, some of which may lyse over the period of incubation. Changes in viral abundance are observed and used to calculate the production of the viral component of the community. Viral decay can be used as a measurement of production, given the assumption that replacement of viruses in the community is equal to the number of viruses lost to decay, and can be measured by inhibiting biological activity. The estimation of decay in this matter is a measurement of production, albeit indirect, and as such can be compared to production estimates.

The goal of the present study was to evaluate viral and prokaryotic communities, and determine the role viruses play in hot spring communities; specifically of interest was the contribution of viruses to the turnover of bacterial communities. Viral production and relative contributions of water vs. sediment/microbial mat material as sources for new viruses were determined. Our results indicate that viruses in these hot spring environments are abundant, active, and play a significant role in the regulation of prokaryotes.

\section{MATERIALS AND METHODS}

Study site, characteristics, and sample collection. All of the study springs were located within the Alvord Desert Basin, in the southeastern corner of Oregon, USA. Alvord is part of the great basin region of the United States and consists of 3 hydrologically distinct basins: Alvord, Borax, and Mickey. The northernmost basin, Mickey, has approximately 57 features; 3 ther- mal springs at Mickey were sampled in January 2004: Tinky Winky (average temperature $=62^{\circ} \mathrm{C}$, average $\mathrm{pH}=8.0$ ); Yellow Pot (average temperature $=61^{\circ} \mathrm{C}$, average $\mathrm{pH}=7.1$ ); and Hot Source (average temperature $=94^{\circ} \mathrm{C}$, average $\mathrm{pH}=8.5$ ). Borax is the southernmost basin and is composed of approximately 250 features. Four springs (Nos. 6 to 9) were sampled in April 2004: No. 6 (average temperature $=77^{\circ} \mathrm{C}$, average $\mathrm{pH}=6.8$ ); No. 7 (average temperature $=88^{\circ} \mathrm{C}$, average $\mathrm{pH}=7.2$ ); No. 8 (average temperature $=60^{\circ} \mathrm{C}$, average $\mathrm{pH}=7.0$ ); and No. 9 (average temperature $=96^{\circ} \mathrm{C}$, average $\mathrm{pH}=7.3$ ). Water and sediment/mat samples were collected from all of the springs. Water was collected using metal tongs and sterile graduated cylinders. Sediment/mat was collected from the upper depths of the spring $(<10 \mathrm{~cm})$ with metal tongs and modified falcon tubes (bottom aseptically removed), enabling the collection of sediment/mat samples without overlying water. Samples were placed into vials containing either glycerol (final concentration $25 \%$ ) or glutaraldehyde (final concentration $2 \%$ ) for prokaryotic and viral assessments, respectively. Glycerol was the preservative of choice because studies have shown that samples can be thawed and frozen several times without influencing their physiological activity (Williams et al. 1998, Howard-Jones et al. 2001); additionally, long-term preservation in alcohol or aldehyde solutions are known to damage cell membranes and thereby decrease cell counts (Decamp \& Rajendran 1998). Sample vials were flash frozen and stored in liquid nitrogen until further analysis (Wen et al. 2004). More detailed information regarding the Alvord Basin is available at www.uidaho.edu/biogeochemistry.

Direct counts of prokaryotes and virus-like particles. Virus-like particles (VLP) were enumerated using epifluorescence microscopy following staining with Yo-Pro-1, as described previously (Hennes \& Suttle 1995). Sample aliquots (2 to $4 \mathrm{ml}$ ) were added to centrifuge tubes containing $5 \mathrm{ml}$ of $0.02 \mu \mathrm{m}$ filtered $10 \mathrm{mM}$ sodium pyrophosphate and $5 \mathrm{mM}$ EDTA in Nanopure water $(2 \%$ glutaraldehyde already present in storage of sample) within $72 \mathrm{~h}$ of sample collection. For each sample $>200$ VLP in 10 randomly selected fields were counted with a Leica DMIRB fluorescence microscope equipped with a 100X UPLANFL NA 1.35 oil objective and Blue (excitation filter BP 470, dichroic mirror DM 500, and barrier filter BA 525) filter set. Prokaryotic cells were enumerated after staining with DAPI (60 $\mu \mathrm{l}$ added $\mathrm{ml}^{-1}$ of sample filtered; final concentration $3 \mu \mathrm{g} \mathrm{ml}^{-1}$ ). In addition, unstained samples were visualized to ensure that background fluorescence was accounted for during total counts for both viruses and bacteria (1 filter per sample). Prokaryotes were visualized with a Wide UV filter set (exciter filter BP 340380, dichroic mirror DM 400, and barrier filter BA 445). 
Estimate of viral production. Production from lysis of attached prokaryotes was determined using methods modified from Hewson \& Fuhrman (2003). Sediment/ mat samples were prepared by first washing the sediment/mat with Nanopure water over a $10 \mu \mathrm{m}$ screen, and then dried in an aluminum pan over a camp stove/oven at approximately $60^{\circ} \mathrm{C}$ for 1 to $2 \mathrm{~h}$. The purpose of heating the material was to remove all of the porewater and associated bacteria and viral particles, such that when reconstituted with virus-free porewater, estimates of sediment-derived production could be made. Virus-free porewater (bacteria and viruses removed) was prepared as previously described (Hewson \& Fuhrman 2003). Dried sediment/mat was reconstituted with filtered porewater by agitation for 2 to $5 \mathrm{~min}$; $100 \mathrm{ml}$ of porewater was added to $40 \mathrm{~g}$ of dried sediment/mat. To determine if all prokaryotes and VLP were removed during the sterilization, sediment/mat samples ( 3 to $5 \mathrm{~g}$ ) were collected prior to reconstitution and stored in glycerol vials for later analysis.

Production from attached and free-living prokaryotes was also determined using methods modified from Hewson \& Fuhrman (2003). Approximately $500 \mathrm{~g}$ of sediment/mat from each sampling location was prepared by first washing and then heating at approximately $200^{\circ} \mathrm{C}$ for $45 \mathrm{~min}$ using a camp stove/oven to kill all prokaryotes and viruses in the sediment/mat material. Portions of heat-killed sediment/mat were reconstituted with virus-free water $(40 \mathrm{~g}$ into $100 \mathrm{ml})$ by agitation. This slurry was amended with $10 \mathrm{~g}$ of freshly collected non-amended sediment/mat from the same spring. This mixture was then mixed thoroughly in sterile Whirlpack bags.

Triplicate incubations for each of these preparations were conducted for samples from 1 spring from each basin (Tinky Winky from the Mickey Basin and No. 9 from Borax) in sterile Whirlpack bags. Incubations were conducted at in situ temperatures for 9 and $36 \mathrm{~h}$ for Tinky Winky and No. 9, respectively. Bags were incubated under natural conditions in the springs by attaching each one to a wooden pole that was placed over the spring. Samples from each replicate were collected at times 0, 3 and $9 \mathrm{~h}$ at Tinky Winky, and 0, 12, and $24 \mathrm{~h}$ at spring No. 9. Viral and prokaryotic abundances were determined using Yo-Pro-1 and DAPI staining. Viral production rates were determined from first-order regressions of viral abundance versus time for triplicate incubations. Viral turnover rates were estimated by dividing production rates by viral abundance for each sample (Wilhelm et al. 2002). The percentage of prokaryotic cells lysed per unit time was calculated by dividing the rate of viral production by an assumed burst size of 20 viruses produced per lytic event (Noble \& Fuhrman 2000, Breitbart et al. 2004), divided by total prokaryotic abundance.
Viral decay experiments. Viral decay (decrease in viral concentration over time) was determined, based on previously described methods (Fischer et al. 2003), after the production of new viruses was inhibited by the addition of KCN (final concentration, $2 \mathrm{mM}$ ). For this approach, one has to assume that the viral abundance in a system remains constant through time and that viruses from lysed bacterial cells replace viruses lost through decay. Sediment/mat slurries comprised $40 \mathrm{~g}$ of sediment/mat material placed in acid-sterilized Kimax $125 \mathrm{ml}$ glass bottles. The bottles were incubated at in situ temperatures (in hot spring; see Fig. 1) and under in situ light:dark conditions. Samples $(5 \mathrm{ml})$ were taken at 3 or 4 time intervals over a $24 \mathrm{~h}$ period. Prior to the removal of samples, the slurry was mixed. Each sample was immediately stored in $2 \%$ glutaraldehyde and flash frozen until it could be filtered and further analyzed. For these experiments, it was assumed that KCN would kill (i.e. inhibit cellular metabolism) all prokaryotic cells in the samples. The effectiveness of KCN at inhibiting bacterial production has not been thoroughly investigated in extreme ecosystems; to address this issue, bacterial abundance was determined in samples over the course of the decay experiment (9 or $24 \mathrm{~h}$ ).

Mitomycin C experiments. Samples from the Alvord Basin were incubated with mitomycin $\mathrm{C}$ according to the methods of Jiang \& Paul $(1996,1998)$. Mitomycin C was added to $100 \mathrm{ml}$ samples to a final concentration of $0.5 \mu \mathrm{g} \mathrm{ml}^{-1}$. At each sampling point, sub-samples for prokaryotic and viral enumeration were taken. Negative control samples without mitomycin $C$ were prepared and incubated simultaneously. The number of induced prokaryotes was estimated as the difference in viral abundance between the treatments divided by an assumed burst size of 20 viruses per cell (Noble \& Fuhrman 2000, Breitbart et al. 2004).

\section{RESULTS}

\section{Spring characteristics}

Within the Borax basin, sequentially numbered springs typically differ from each other by approximately 15 to $30^{\circ} \mathrm{C}$ in temperature at the time of sampling $\left(61\right.$ to $\left.96^{\circ} \mathrm{C}\right)$. The springs within the Mickey basin varied in temperature from 61 to $94^{\circ} \mathrm{C}$, and also exhibited varying amounts of visible mat material or sinters (chemical crusts that were deposited by the mineral spring; Fig. 1). All of the springs are hydrologically distinct. The springs in both basins have circumneutral $\mathrm{pH}$ and are characterized as sodium-bicarbonatechlorine type with high concentrations of arsenic $(0.9$ to $1.2 \mathrm{mg} \mathrm{l}^{-1}$ ) and borate (9.6 to $14.5 \mathrm{mg} \mathrm{l}^{-1}$; see www. uidaho.edu/biogeochemistry). 

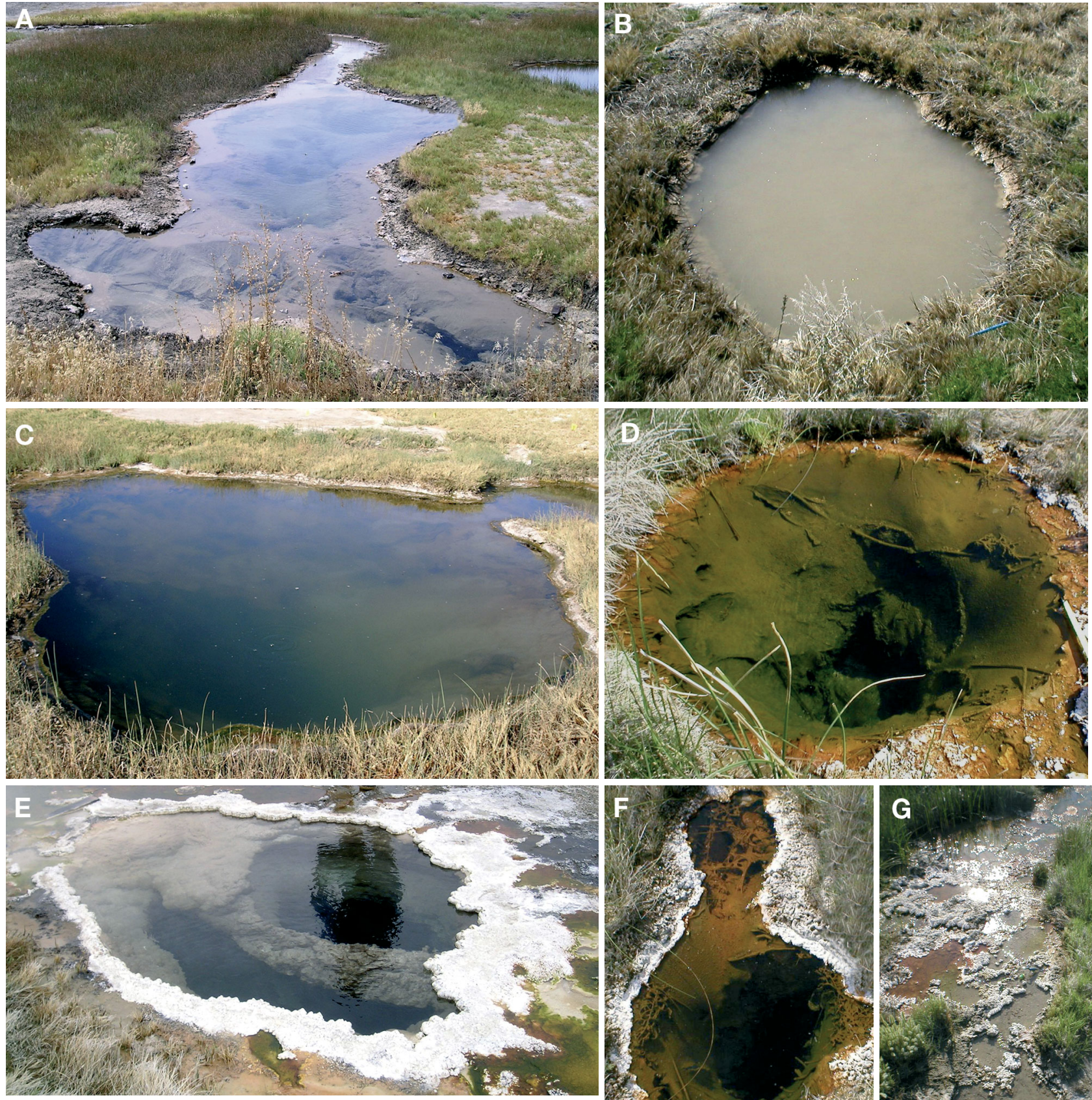

Fig. 1. Hot springs sampled in Mickey basin (A: Hot Source; B: Yellow Pot; C: Tinky Winky) and Borax basin (D-G: spring Nos. 6 to 9, respectively), Alvord Desert, USA. (Photos printed with permission from Dr. Jerry Fairley, University of Idaho)
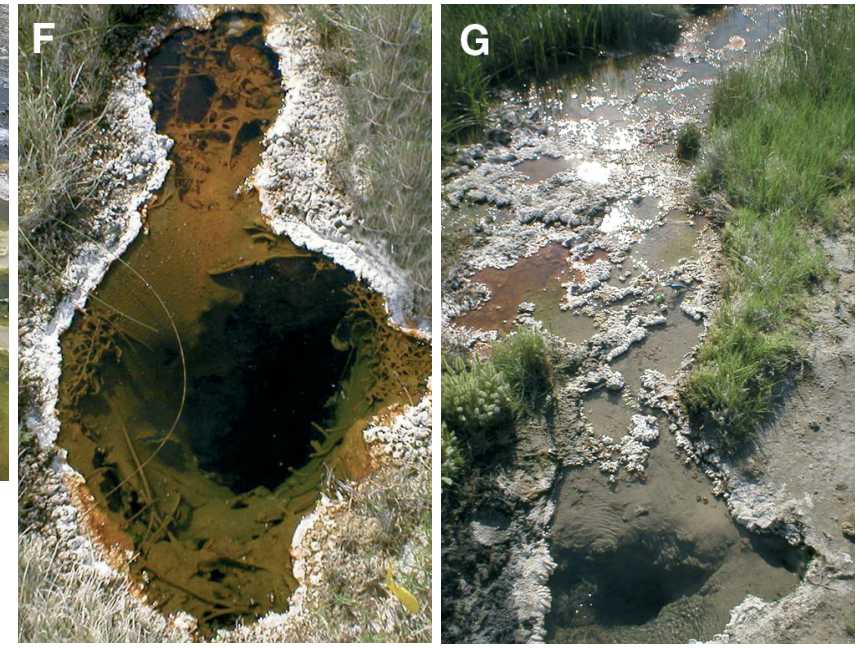

\section{Prokaryotic and viral abundance}

Total prokaryotic abundance in situ ranged from 3.57 to $9.48 \times 10^{5}$ cells ml ${ }^{-1}$ and viral abundance from 3.77 to $7.76 \times 10^{6} \mathrm{VLP} \mathrm{ml}^{-1}$ (Table 1 ). Virus-tobacterium ratios (VBR) were calculated from abundance data and ranged from 4.81 to 18.87 (Table 1).
The average for all of the springs sampled was 10.52 VLP per prokaryotic cell. There was no significant difference between the VBR ratios of the 2 basins sampled (ANOVA, $\mathrm{p}<0.05$ ). There was also no significant difference between ratios determined for water and sediment/mat samples (ANOVA, $\mathrm{p}<0.05$; data not shown). 
Table 1. Bacterial and viral abundance (mean of 30 determinations with $1 \mathrm{SD}$ ) and viral-to-bacterium ratios (VBR) for hot springs sampled at Mickey and Borax basins, Alvord Desert, USA, during winter 2004. Sediment evaluations are italicized. YP: Yellow Pot; TW: Tinky Winky; HS: Hot Source

\begin{tabular}{|clrrr|}
\hline \multirow{2}{*}{$\begin{array}{c}\text { Basin/ } \\
\text { spring }\end{array}$} & \multirow{2}{*}{ Type } & \multicolumn{2}{c}{$\begin{array}{c}\text { Abundance } \\
\text { Bacterial }\end{array}$} & \multirow{2}{*}{ VBR } \\
& & $\left(10^{5}\right.$ cells $\left.^{-1}\right)$ & $\left(10^{6} \mathrm{VLP} \mathrm{ml}^{-1}\right)$ & \\
\cline { 3 - 4 } Mickey & & & \\
YP & Water & $3.79 \pm 0.83$ & $7.15 \pm 1.22$ & 18.87 \\
& Sediment & $16.75 \pm 1.27$ & $29.34 \pm 2.51$ & 17.49 \\
TW & Water & $9.48 \pm 1.12$ & $4.56 \pm 0.89$ & 4.81 \\
HS & Water & $7.68 \pm 0.73$ & $4.14 \pm 1.10$ & 5.39 \\
Borax & & & & \\
No. 6 & Water & $3.85 \pm 0.52$ & $6.67 \pm 0.81$ & 17.32 \\
No. 7 & Water & $7.85 \pm 0.94$ & $4.15 \pm 0.57$ & 5.29 \\
& Sediment & $5.91 \pm 0.77$ & $21.24 \pm 1.37$ & 3.59 \\
No. 8 & Water & $3.57 \pm 0.21$ & $3.77 \pm 0.78$ & 10.56 \\
& Sediment & $18.44 \pm 1.98$ & $31.42 \pm 2.44$ & 17.04 \\
No. 9 & Water & $6.78 \pm 0.42$ & $7.76 \pm 0.88$ & 11.44 \\
& & & & \\
\hline
\end{tabular}

\section{Viral production}

The abundance of VLPs increased linearly with time in the 2 springs tested: Tinky Winky at Mickey basin (Fig. 2A) and spring No. 9 at Borax (Fig. 2B). Bacterial and VLP abundance and production rates were generally higher in sediment/mat samples than in water samples (Table 2). Viral turnover rates were similar within springs from each basin $\left(1.00\right.$ and $0.98 \mathrm{~h}^{-1}$ for Mickey basin, $0.27 \mathrm{~h}^{-1}$ for Borax basin; Table 2). Assuming a burst size of 20 , the resulting lysis rates were estimated as 9 to $26 \%$ removal of the total prokaryotic community $\mathrm{h}^{-1}$.

\section{Viral decay}

Results from the decay time course experiments are shown in Fig. 3. All experiments revealed similar patterns of decrease in viral abundance when viral production was chemically inhibited with KCN. The first series of experiments at springs within the Mickey basin (Hot Source, Tinky Winky, and Yellow Pot) was carried out for $9 \mathrm{~h}$; decay rates in these springs ranged from 0.09 to $0.2 \mathrm{~h}^{-1}$, which correspond to viral turnover times ranging from 5 to $11 \mathrm{~h}$. Decay rates at springs within Borax basin (Nos. 6 to 9) ranged from 0.07 to $0.08 \mathrm{~h}^{-1}$, corresponding to viral turnover times of 12 to $14 \mathrm{~h}$. Viral turnover

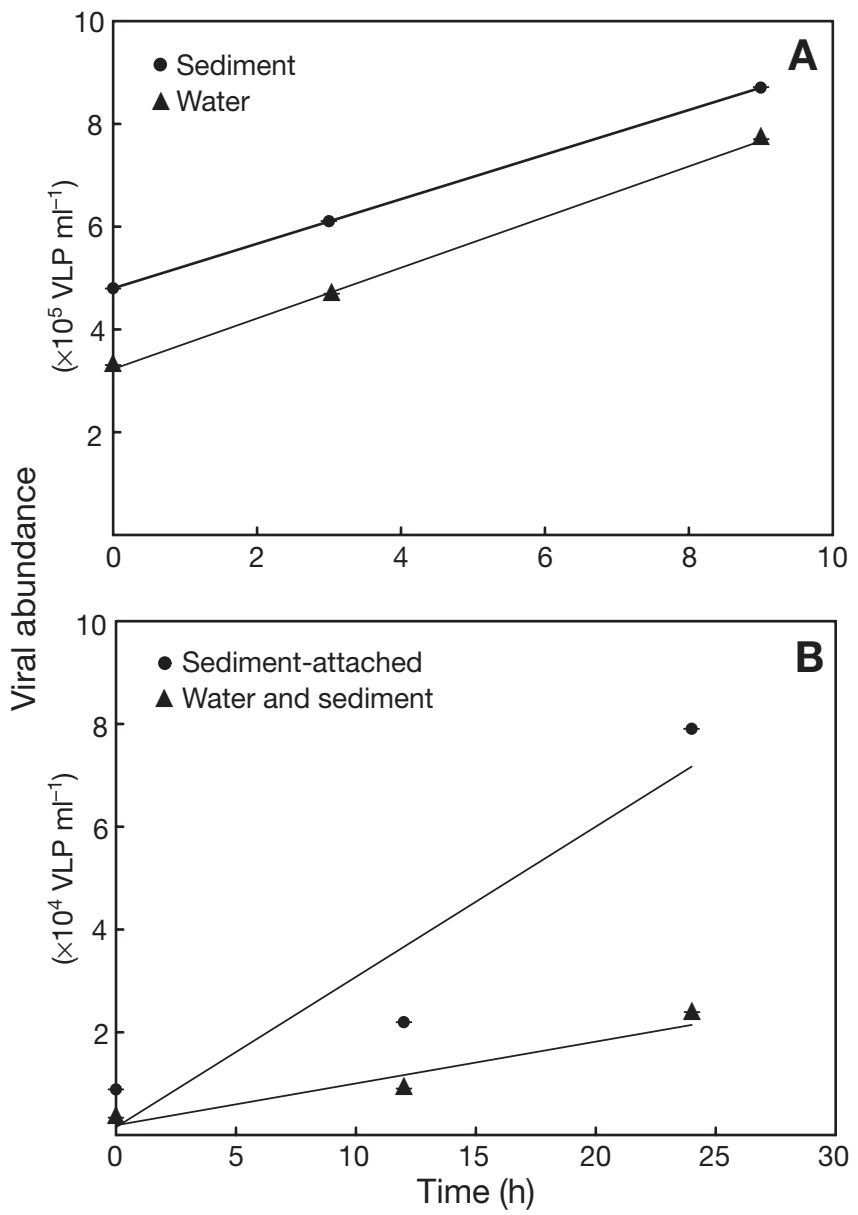

Fig. 2. Changes in viral abundance during field incubations of water from (A) spring No. 9 at Borax basin, and (B) Tinky Winky at Mickey basin. Circles indicate results of incubations of attached microbial community (sediment/mat samples) and production of viruses from lysis of those bacteria over time. Lines represent incubations with both water and sediment/ mat microbial and viral populations. Viral production rates were determined from first-order regressions of viral abundances over time. Error bars = mean $+1 \mathrm{SD}(\mathrm{n}=3)$. VLP: virus-like particles

Table 2. Viral production, abundance, turnover, and the percentage of prokaryotes destroyed by viral lysis. Values for viral and bacterial abundance are the result of sampling during the production experiment (not whole, unaltered samples as in Table 1). Sediment (Sed.) evaluations are italicized

\begin{tabular}{|c|c|c|c|c|c|c|}
\hline \multirow{2}{*}{$\begin{array}{l}\text { Basin/ } \\
\text { spring }\end{array}$} & \multirow{2}{*}{ Type } & \multirow{2}{*}{$\begin{array}{c}\text { Viral } \\
\text { production } \\
\left(10^{4} \mathrm{ml}^{-1} \mathrm{~h}^{-1}\right)\end{array}$} & \multicolumn{2}{|c|}{ Abundance } & \multirow{2}{*}{$\begin{array}{l}\text { Viral } \\
\text { turnover } \\
\left(\mathrm{h}^{-1}\right)\end{array}$} & \multirow{2}{*}{$\begin{array}{c}\% \text { cells } \\
\text { lysed } \\
\left(\mathrm{h}^{-1}\right)\end{array}$} \\
\hline & & & $\begin{array}{c}\text { Viral } \\
\left(10^{5} \mathrm{VLP} \mathrm{ml}^{-1}\right)\end{array}$ & $\begin{array}{c}\text { Bacterial } \\
\left(10^{4} \text { cells ml }^{-1}\right)\end{array}$ & & \\
\hline \multicolumn{7}{|l|}{ Mickey } \\
\hline Tinky & Sed. & 4.8 & 4.8 & 9.1 & 1.0 & 26.37 \\
\hline Winky & Water & 3.23 & 3.3 & 9.48 & 0.98 & 17.03 \\
\hline \multicolumn{7}{|l|}{ Borax } \\
\hline \multirow[t]{2}{*}{ No. 9} & Sed. & 0.16 & 0.6 & 0.89 & 0.27 & 8.98 \\
\hline & Water & 0.19 & 0.71 & 0.94 & 0.27 & 10.1 \\
\hline
\end{tabular}




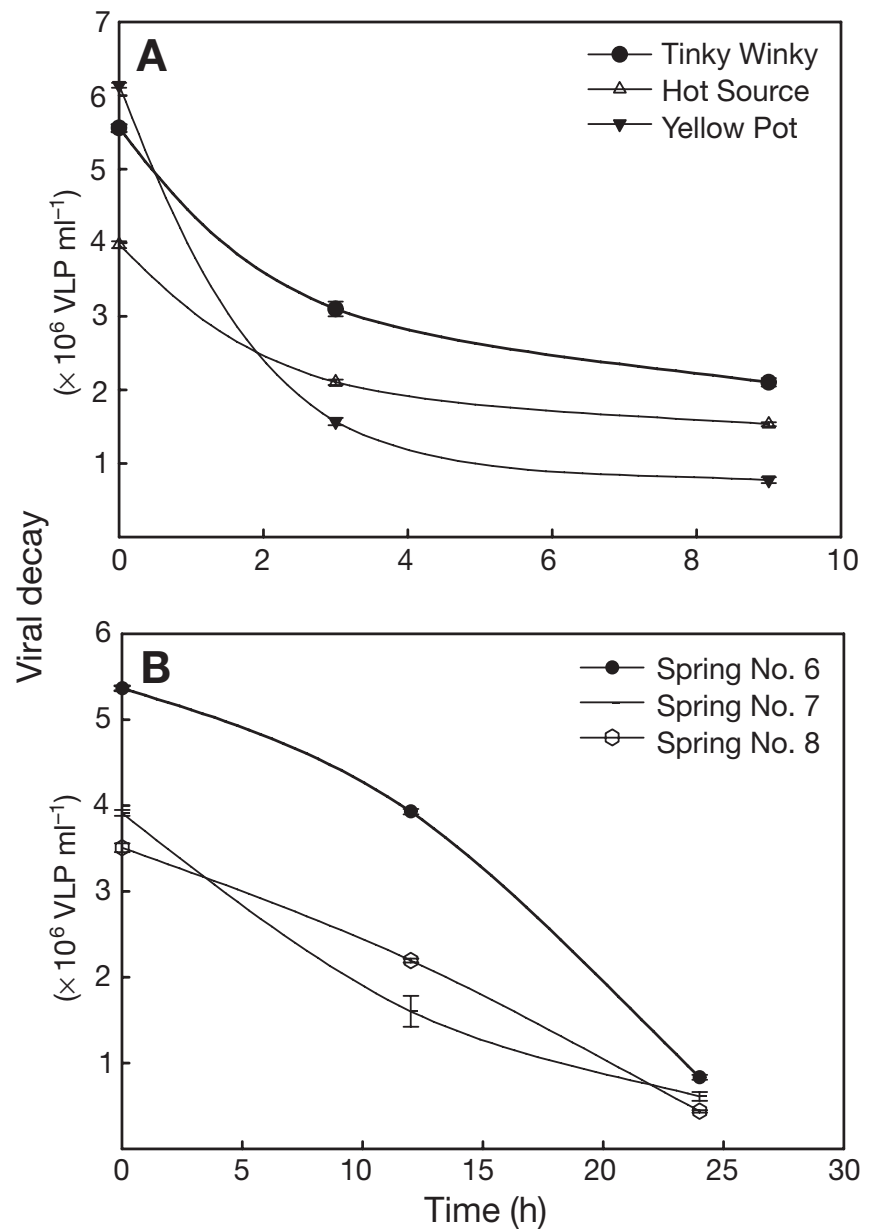

Fig. 3. Viral decay over time following inhibition of viral production with KCN. (A) Decay at springs Tinky Winky, Hot Source, and Yellow Pot within the Mickey basin. (B) Spring Nos. 6,7 and 8 within the Borax basin. Error bars $= \pm \mathrm{SD}$ of 3 replicates

rates were significantly higher when estimated based on production vs. decay data (ANOVA, $\mathrm{p}<0.05$ ). In order to address the issue of whether or not $\mathrm{KCN}$ would kill all prokaryotic cells equally, bacterial abundance was evaluated over time. Abundance decreased slightly (ANOVA, p < 0.05) in both experiments over time, when comparing $t_{0}$ and $t_{\text {final }}$. Abundance was approximately 45 and $58 \%$ less than the total bacterial abundance determined from controls. A more direct estimate of the effectiveness of $\mathrm{KCN}$ would be bacterial production estimates, which were not undertaken in this study.

\section{Induction of prophages by mitomycin C}

The results of mitomycin $\mathrm{C}$ incubations are shown in Fig. 4. Treatment of hot springs water with the DNAdamaging agent resulted in significant decreases in

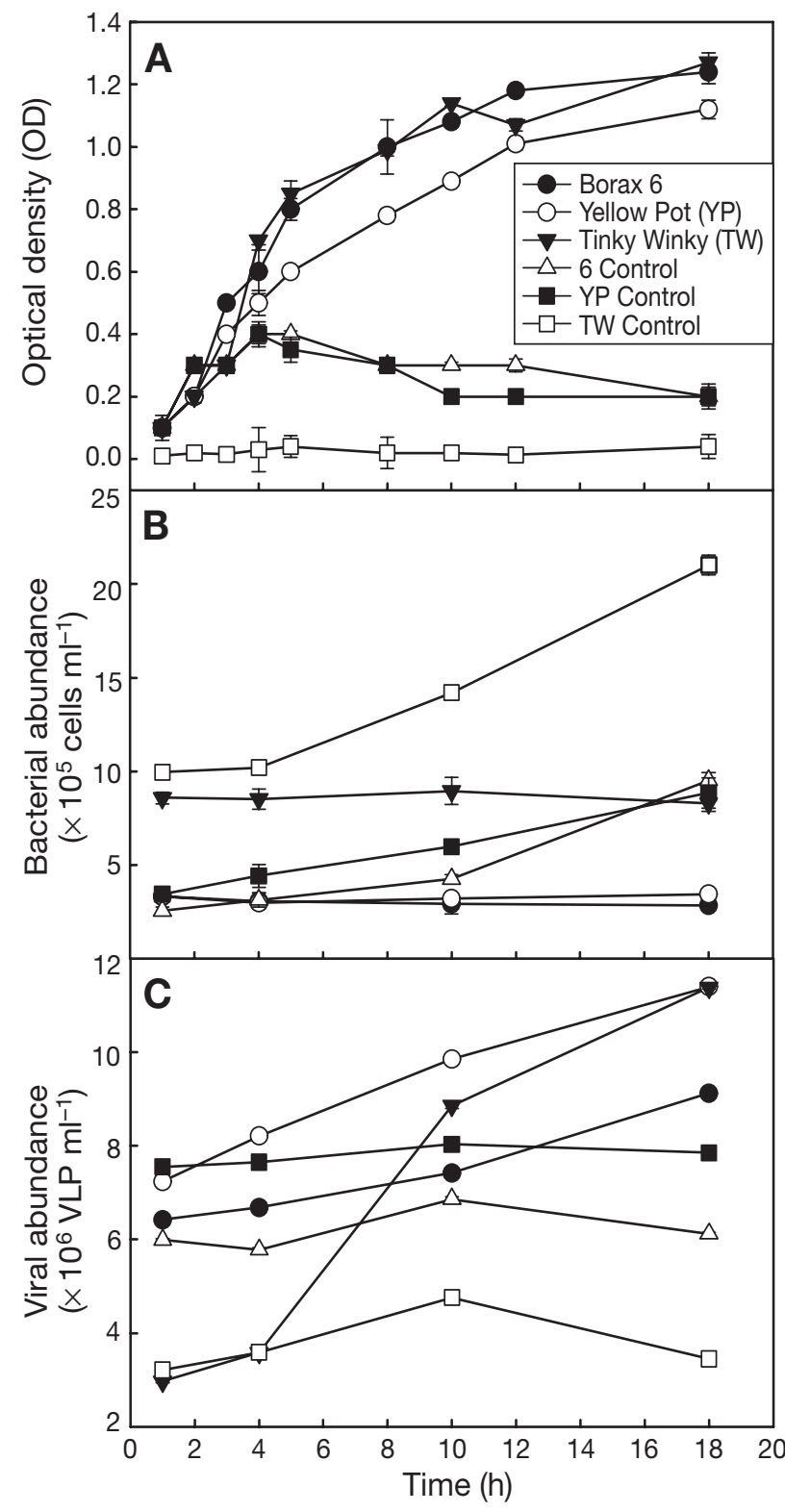

Fig. 4. (A) Optical density and (B,C) abundances of (B) prokaryotes and $(\mathrm{C})$ total viruses in untreated (control) and mitomycin-C-treated samples over time. Error bars $= \pm \mathrm{SD}$ of 3 replicates

overall optical density in the spring water samples (Fig. 4A), decreased prokaryotic counts (Fig. 4B), and increases in VLP numbers (Fig. 4C), compared with control incubations. These results were attributed to phage production as a result of induction and lysis of lysogenic prokaryotes. From this, it is estimated that between 18 and $21 \%$ of the prokaryotes present at the start of the incubation were lysogenic (Borax: No. 6, $18.07 \%$; Mickey springs: Tinky Winky, $18.46 \%$ and Yellow Pot, 21.26\%). 


\section{DISCUSSION}

The results presented here demonstrate that freeliving viruses are ubiquitous and abundant (in excess of one million $\mathrm{ml}^{-1}$ ) in hot spring sediment/mat material and in overlying hot spring water, regardless of the temperature of springs sampled $\left(61\right.$ to $96^{\circ} \mathrm{C}$ ). VLP abundance was lower than reported for other aquaticsediment environments including freshwater (Maranger \& Bird 1995, Danovaro et al. 2002), yet was similar to abundances determined for similar extreme ecosystems (Breitbart et al. 2004, Weinbauer 2004). However, the VBRs determined for all of the springs sampled were the same order of magnitude as those previously reported for sediments (Maranger \& Bird 1996, Drake et al. 1998, Hewson et al. 2001). There was no correlation between abundance of prokaryotes or viruses and spring temperature, but rather it appeared that regardless of the spring sampled, both population densities were statistically similar (ANOVA, $p=0.4$ and 0.8 prokaryotes and viruses, respectively).

While the overall numbers of VLPs were similar at springs sampled in Borax and Mickey basins, production measurements at Tinky Winky were significantly higher (ANOVA, $\mathrm{p}<0.05$ ) than at spring No. 9. Differences in the production rates are not likely attributable to geochemical parameters, as waters from different springs within and between these basins exhibited remarkably coherent chemical characteristics, in spite of variations in temperature. The lower rates measured at spring No. 9 may be a reflection of the temperature difference between the springs evaluated; No. 9, with an average temperature 30 to $35^{\circ} \mathrm{C}$ hotter, displayed lower total viral and prokaryotic densities and production rates. Despite variations, production estimates reveal that viruses are actively produced and account for a significant percentage of prokaryotic mortality.

Assuming an estimate of 20 VLP per infected bacterium (Noble \& Fuhrman 2000, Breitbart et al. 2004), viruses in this ecosystem were determined to cause lysis of an average $9.5 \%$ (No. 9) and $21.7 \%$ (Tinky Winky) of prokaryotic cells $\mathrm{h}^{-1}$ (sediment and water), similar to viral production rates previously reported for sediments (10 to $20 \% \mathrm{~h}^{-1}$; Danovaro \& Serresi 2000, Hewson \& Fuhrman 2003).

In addition to direct measurements of production, a method for evaluating viral decay was employed (Heldal \& Bratbak 1991). This method estimates production indirectly by assuming a balance of viruses in the system (viruses produced from lysed prokaryotes and lost through decay). Based on this approach, decay rates measured at both basins (Mickey and Borax) were not significantly different (ANOVA, $\mathrm{p}=0.07$ ), ranging from 0.07 to $0.20 \mathrm{~h}^{-1}$, with average turnover times of 8.70 and $13.36 \mathrm{~h}$ for the viral populations within the
Mickey and Borax basins, respectively. Both approaches for determining viral production and prokaryotic turnover rates have limitations which are addressed in the literature (Wommack \& Colwell 2000, Hewson \& Fuhrman 2003).

While lytic viral population size and infectivity are important metrics to consider in understanding microbial community dynamics, lysogenic viruses also contribute to bacterial production, diversity, and overall community structure (Weinbauer 2004). Lysogeny is important to evaluate in natural ecosystems, not only because of the potential for eventual cell lysis, but also because of results suggesting that prophages may confer competitive advantages to prokaryotic hosts. Specifically, infected host cells may exhibit more rapid replication rates (Edlin et al. 1977), exhibit prophage-encoded antibiotic resistance (Smith 1972), or utilize other virulence factors carried by the virus (Barondess \& Beckwith 1990). In the present study, mitomycin C induced lysis of 18 to $21 \%$ of the prokaryotic community. Because not all lysogens can be induced with mitomycin $\mathrm{C}$, these results represent a conservative estimate of lysogenic prokaryotes. This study falls within the range reported previously for natural communities - $0.07 \%$ (Weinbauer \& Suttle 1996) to $80 \%$ (Ortmann et al. 2002) induced by mitomycin Cand indicates that lysogeny is important in extreme ecosystems.

\section{CONCLUSIONS}

While many aquatic environments have been analyzed for viral abundance and dynamics, hot spring systems have only recently been investigated with respect to free-living viral populations (Breitbart et al. 2004, present study). Results of both of these studies support the conclusion that viruses are abundant and active in thermal environments. This study clearly demonstrates that both mat-derived and overlying water viral communities are important members of hot spring ecosystems, contributing significantly to prokaryotic loss and turnover. These studies raise interesting questions regarding the effect of viruses on microbial diversity and community structure, especially in an environment with a simplified food web, where direct effects of viruses on microbial populations should be magnified.

Acknowledgements. We thank S. Clingenpeel, J. Niebecker, and J. Lee for assistance during field sample collection and analysis, and B. D. Lee for access and use of lab facilities at the Idaho National Laboratory in Idaho Falls. We also thank our collaborators at the University of Idaho, L. Fairley and his graduate students for their work in cataloging and geochemically characterizing the thermal springs and pools in all of the basins at Alvord. 


\section{LITERATURE CITED}

Barondess JJ, Beckwith J (1990) Gene of Phage l, involved in serum resistance, encodes a widely conserved outer membrane lipoprotein. J Bacteriol 177:1247-1253

Bratbak G, Heldal M, Thingstad TF, Riemann B, Haslund OH (1992) Incorporation of viruses into the budget of microbial C-transfer. A first approach. Mar Ecol Prog Ser 83: 273-280

Breitbart M, Wegley L, Leeds S, Schoenfeld T, Rohwer F (2004) Phage community dynamics in hot springs. Appl Environ Microbiol 70:1633-1640

Danovaro R, Serresi M (2000) Viral density and virus-tobacterium ratio in deep sea sediments of the eastern Mediterranean. Appl Environ Microbiol 66:1857-1861

Danovaro R, Manini E, Dell'Anno A (2002) Higher abundance of bacteria than of viruses in deep Mediterranean sediments. Appl Environ Microbiol 68:1468-1472

Decamp O, Rajendran N (1998) Bacterial loss and degradation of bacterial membrane in preserved seawater samples. Mar Pollut Bull 36:856-859

Drake LA, Choi KH, Haskell E, Dobbs FC (1998) Vertical profiles of virus-like particles and bacteria in the water column and sediments of Chesapeake Bay, USA. Aquatic Microbial Ecology 16:17-25

Edlin G, Lin L, Bitner R (1977) Reproductive fitness of P1, P2, and Mu lysogens of Escherichia coli. J Virol 21:560-564

Fischer UR, Wieltshnig C, Kirschner AKT, Velimirov B (2003) Does viral-induced lysis contribute significantly to bacterial mortality in the oxygenates sediment layer of shallow Oxbow lakes? Appl Environ Microbiol 69: $5281-5289$

Fuhrman JA (1999) Marine viruses and their biogeochemical and ecological effects. Nature 399:541-548

Fuhrman JA, Suttle CA (1993) Viruses in marine planktonic systems. Oceanography 6:51-63

Guixa-Boixereu N, Calderon-Paz JI, Heldal M, Bratbak G, Pedros-Alio C (1996) Viral lysis and bacterivory as prokaryotic loss factors along a salinity gradient. Aquat Microb Ecol 11:215-227

Hambly E, Suttle CA (2005) The viriosphere, diversity, and genetic exchange within phage communities. Curr Opin Microbiol 8:444-450

Haring M, Rachel R, Peng X, Garrett RA, Prangishvilli D (2005) Viral diversity in hot springs of Pozzuoli, Italy, and characterization of a unique archaeal virus, Acidianus, bottle-shaped virus, form a new family, Ampullaviridae. J Virol 79:9904-9911

Heldal M, Bratbak G (1991) Production and decay of viruses in aquatic environments. Mar Ecol Prog Ser 72:205-212

Hennes KP, Suttle CA (1995) Direct counts of viruses in natural waters and laboratory cultures by epifluorescence microscopy. Limnol Oceanogr 40:1050-1055

Hewson I, Fuhrman JA (2003) Viriobenthos production and virioplankton sorptive scavenging by suspended sediment particles in coastal and pelagic waters. Microb Ecol 46: 337-347

Hewson I, O'Neil JM, Fuhrman JA, Dennison WC (2001) Virus-like particle distribution and abundance in sediments and overlying waters along eutrophication gradi-

Editorial responsibility: Gerhard Herndl, Den Burg, Texel, The Netherlands ents in two subtropical estuaries. Limnol Oceanogr 46: $1734-1746$

Howard-Jones MH, Frischer ME, Verity PG (2001) Determining the physiological status of individual bacterial cells. In: Paul JH (ed) Methods in microbiology: marine microbiology, Vol 30. Academic Press, San Diego, CA, p 175-206

Jiang S, Paul JH (1996) Occurrence of lysogenic bacteria in marine microbial communities as determined by prophage induction. Mar Ecol Prog Ser 142:27-38

Jiang S, Paul JH (1998) Significance of lysogeny in the marine environment: studies with isolates and a model of lysogenic phage production. Microb Ecol 35:235-243

Maranger R, Bird DF (1995) Viral abundance in aquatic systems: a comparison between marine and fresh waters. Mar Ecol Prog Ser 121:217-226

Marange R, Bird DF (1996) High concentrations of viruses in the sediments of Lac Gilbert, Québec. Microb Ecol 31:141-151

Noble RT, Fuhrman JA (2000) Rapid virus production and removal as measured with fluorescently labeled viruses as tracers. Appl Environ Microbiol 66:3790-3797

Ortmann AC, Lawrence JE, Suttle CA (2002) Lysogeny and lytic viral production during a bloom of the cyanobacteria Synechococcus spp. Microb Ecol 43:225-231

Rice G, Stedman K, Snyder JC, Wiedenheft B, Willits D, Brumfield S, McDermott T, Young M (2001) Viruses from extreme thermal environments. Proc Natl Acad Sci USA 98:13341-13345

Rice G, Tang L, Stedman K, Roberto F and 5 others (2004) The structure of thermophilic archaeal virus shows doublestranded DNA viral capsid type that spans all domains of life. Proc Natl Acad Sci USA 101:7716-7720

Smith HW (1972) Ampicillin resistance in Escherichia coli by phage infection. Nat New Biol 238:205-206

Weinbauer MG (2004) Ecology of prokaryotic viruses. FEMS Microbiol Rev 28:127-181

Weinbauer MG, Rassoulzadegan F (2004) Are viruses driving microbial diversification and diversity? Environ Microbiol $6: 1-11$

Weinbauer MG, Suttle CA (1996) Potential significance of lysogeny to bacteriophage production and bacterial mortality in coastal waters of the Gulf of Mexico. Appl Environ Microbiol 62:4374-4380

Wen K, Ortmann AC, Suttle CA (2004) Accurate estimation of viral abundance by epifluorescence microscopy. Appl Environ Microbiol 70:3862-3867

Wilhelm SW, Suttle CA (1999) Viruses and nutrient cycles in the sea. BioScience 49:781-788

Wilhelm SW, Brigden SM, Suttle CA (2002) A dilution technique for the direct measurement of viral production: a comparison in stratified and tidally mixed coastal waters. Microb Ecol 43:168-173

Williams SC, Hong Y, Danavall DCA, Howard-Jones MH, Gibson D, Frischer ME, Verity PG (1998) Distinguishing between living and nonliving bacteria: evaluation of the vital stain propidium iodide and its combined use with molecular probes in aquatic samples. J Microbiol Methods 32:225-236

Wommack KE, Colwell RR (2000) Virioplankton: viruses in aquatic ecosystems. Microbiol Mol Biol Rev 64:69-114

Submitted: October 4, 2006; Accepted: March 19, 2007

Proofs received from author(s): June 11, 2007 